\title{
POTENSI PENINGKATAN EUROSKEPTISISME DI NEGARA INTI UNI EROPA
}

\author{
Hafid Adim Pradana ${ }^{1}$, Ruli Inayah Ramadhoan ${ }^{2}$ \\ ${ }^{1,2}$ Program Studi Hubungan Internasional Universitas Muhammadiyah Malang \\ Email: adimhafid@umm.ac.id ${ }^{1}$, ruliramadhoan@umm.ac.id ${ }^{2}$
}

\begin{abstract}
Abstrak
Berlarutnya persoalan imigrasi dan krisis finansial yang dihadapi oleh Uni Eropa baru-baru ini memunculkan kembali kesangsian dari negara-negara anggota Uni Eropa akan perlu tidaknya mereka untuk bertahan dalam Uni Eropa. Hal ini kemudian dikenal sebagai Euroskeptisisme. Keluarnya Inggris dari Uni Eropa pasca referendum Brexit tahun 2016 semakin memperkuat anggapan akan menguatnya euroskeptisisme di negara-negara Uni Eropa. Berangkat dari hal tersebut, penelitian ini berupaya untuk mengetahui seberapa signifikan perkembangan euroskeptisisme di negara-negara Uni Eropa, yang meliputi Perancis, Belanda, Jerman, Italia, Belgia, dan Luksemburg, melalui perbandingan hasil kontestasi antar partai dalam tiga penyelenggaraan pemilihan umum terakhir. Keenam negara tersebut dipilih karena merupakan negara inti yang mengawali terbentuknya integrasi Eropa.Indikator yang digunakan untuk mengukur perkembangan euroskeptisisme ialah dengan melihat capaian hasil partai sayap kanan atau nasionalis dalam setiap pemilihan umum.Dengan menggunakan metode komparatif dan teknik analisa data kuantitatif, penelitian ini menghasilkan temuan bahwa terdapat peningkatan euroskeptisisme yang cukup signifikan di Perancis, Belanda, dan Italia, serta berpotensi untuk mengadakan referendum sebagaimana yang telah dilakukan oleh Inggris.
\end{abstract}

\section{Kata Kunci: \\ Euroskeptisisme, Partai Sayap Kanan, Pemilihan Umum, Uni Eropa}

\begin{abstract}
The recent eradication of immigration and financial crises faced by the European Union has revived doubts from EU member states that they will need to survive in the European Union. This became known as Euroskepticism. The exit of the UK from the European Union after the Brexit referendum in 2016 further strengthened the notion of a strengthening euroskepticism in European Union countries. Departing from this, this study seeks to find out how significant the development of euroskepticism in European Union countries, which includes France, the Netherlands, Germany, Italy, Belgium and Luxembourg, through comparison of the results of inter-party contestation in the last three elections. The six countries were chosen because they are the core countries that started the formation of European integration. The indicator used to measure the development of euroskepticism is by looking at the results of the right-wing or nationalist party results in each general election. Using comparative methods and quantitative data analysis techniques, this study produced findings that there was a
\end{abstract}


significant increase in euroskepticism in France, the Netherlands, and Italy, and the potential to hold a referendum as the British had done.

Keywords:

European Union, Euroskepticism, General Election, Right Wings Party

\section{Pendahuluan}

Referendum Britain Exit (Brexit) yang berdampak pada keluarnya keanggotaan Inggris Raya dari Uni Eropa telah menandai semakin kuatnya Euroskeptisisme di Eropa. Euroskeptisisme sendiri secara umum sering dipahami sebagai kesangsian akan keberadaan Uni Eropa. Wujud kesangsian akan keberadaan Uni Eropa sebenarnya telah tampak sejak awal berdirinya Uni Eropa, khususnya pasca pemberlakuan perjanjian Maastricht pada 1993. Kesangsian tersebut, meski masih dalam skala kecil, dapat dilihat dari keberadaan partai-partai sayap kanan yang terdapat di negara-negara anggota Uni Eropa. ${ }^{1} \quad$ Partai-partai sayap kanan ini dalam perjalanannya senantiasa mengkampanyekan tentang hal-hal negatif dari keberadaan Uni Eropa.

Sebagai integrasi regional terbesar di kawasan Eropa, Uni Eropa menghadapi berbagai persoalan yang berdampak pada munculnya pro dan kontra antar negara didalamnya. ${ }^{2}$ Terdapat dua persoalan besar dalam Uni Eropa yang terjadi sejak pergantian milenium. Persoalan pertama ialah terjadinya Krisis Yunani pada 2009 yang disebabkan oleh tingginya kesejahteraan hidup masyarakat Yunani yang ternyata banyak ditopang oleh subsidi dari pemerintah. Subsidi yang diberikan oleh pemerintah Yunani ini sebagian besar berasal dari hutang luar negeri. Hal tersebut kemudian membuat Uni Eropa (UE) memberikan dana talangan atau pinjaman ke Yunani dengan syarat bahwa pemerintah Yunani harus mengadopsi langkah-langkah penghematan dan reformasi pasar tenaga kerja saat menerima pinjaman. Selama tahun 2009 hingga 2014, Bank Sentral Eropa, Uni Eropa dan IMF telah meminjamkan Yunani dua paket uang bantuan sebesar 240 milyar euro. Kebijakan dari UE ini pada perkembangannya

${ }^{1}$ Robert Harmsen \& Menno Spiering (eds), Euroscepticism: Party Politics, National Identity and European Integration (Amsterdam: Rodopi, 2004), h. 14.

${ }^{2}$ Andrew Heywood, Global Politics (London: Macmillan International Higher Education, 2014), h. 501. 
mendapatkan penolakan dari masyarakat Yunani, yang membuat pemerintah Yunani sempat berencana untuk mengeluarkan Yunani dari zona Euro. ${ }^{3}$

Persoalan kedua yang dihadapi oleh UE ialah permasalahan kedatangan pengungsi dari Timur Tengah sebagai efek dari berlarutnya konflik internal Suriah. ${ }^{4}$ Kedatangan para pengungsi dalam jumlah besar telah menimbulkan pro dan kontra diantara negara-negara Uni Eropa. Sebagian negara seperti Jerman dan Perancis memilih untuk menyediakan tempat penampungan bagi para pengungsi. Sementara sebagian lainnya seperti Austria dan Hungaria memilih untuk menolak kedatangan pada pengungsi. Selain pro dan kontra dalam Uni Eropa, persoalan kedatangan para pengungsi juga mendapatkan penolakan oleh sebagian masyarakat di negara-negara Uni Eropa, termasuk di Jerman dan Perancis. Hal ini pada gilirannya memicu adanya Euroskeptisisme yang banyak dikampanyekan oleh berbagai partai sayap kanan di negara-negara Uni Eropa.

Selain persoalan keamanan, munculnya Euroskeptisisme juga berkaitan dengan potensi kerugian yang harus ditanggung oleh negara-negara Uni Eropa, terutama Jerman dan Perancis, jika krisis finansial yang dialami oleh Yunani, yang kemudian menyebar ke Italia, Spanyol, dan Portugal terulang kembali. Sebagian masyarakat di Jerman dan Perancis beranggapan bahwa adalah suatu hal yang merugikan jika negara mereka harus memberikan dana talangan melalui Uni Eropa terhadap negara-negara yang sedang menghadapi krisis finansial. Hal ini tentunya semakin memudahkan partai-partai sayap kanan untuk mengajak masyarakat di negara-negara Uni Eropa guna mengevaluasi kembali keberadaan Uni Eropa. Berbagai fenomena tersebut menunjukkan adanya perkembangan Euroskeptisisme di Uni Eropa.

Berangkat dari fakta diatas, penelitian ini bertujuan untuk mengetahui apakah Euroskeptisisme mengalami perkembangan yang signifikan di negara-negara anggota Uni Eropa.Guna mempermudah bahasan, tulisan ini akan penulis bagi dalam empat bagian. Bagian pertama merupakan kajian pustaka yang berisi tinjauan berbagai literatur penelitian yang membahas tentang Euroskeptisisme. Tinjauan literatur ini penting karena melalui penelaahan berbagai literatur, tulisan ini akan mampu menunjukan aspek

\footnotetext{
${ }^{3}$ Georgios P. Kouretas \& Prodromos Vlamis, “The Greek Crisis: Causes and Implications" dalam Panoeconomicu, Vol. 57, No. 4 (October, 2010), h. 391.

${ }^{4}$ Richard W. Mansbach \& Kirsten L. Taylor, Introduction to Global Politics (Oxford: Routledge, 2007), h. 247.
} 
orisinalitasnya, mengingat cukup banyaknya penelitian-penelitian sebelumnya yang membahas tentang Euroskeptisisme. Pada bagian ini, secara otomatis juga akan diuraikan penjelasan Euroskeptisisme secara konseptual beserta tipologinya. Bagian kedua merupakan pemaparan mengenai metode penelitian yang digunakan dalam riset ini.Bagian berikutnya merupakan inti dari tulisan ini, yaitu penjelasan mengenai eksistensi partai-partai politik di enam negara inti Uni Eropa yang meliputi Perancis, Jerman, Italia, Belanda, Belgia, dan Luxemburg. Bahasan pada bagian ini nantinya akan mampu memberikan gambaran tentang sejauh mana euroskeptisisme berkembang di negara-negara Uni Eropa. Bagian terakhir ialah kesimpulan.

\section{Tinjauan Pustaka}

Terdapat cukup banyak literatur penelitian yang membahas tentang Euroskeptisisme. Dari berbagai literatur tersebut, secara umum terdapat dua jenis bahasan yang dapat ditemui yaitu mengenai pemaparan euroskeptisisme secara konseptual dan studi kasus tentang Euroskeptisisme di negara-negara Uni Eropa. Salah satu literatur terkemuka yang membahas secara mendalam tentang Euroskeptisisme ialah artikel prosiding yang ditulis oleh Alex Szczerbiak dan Paul Taggart yang membahas tentang klasifikasi dari Euroskeptisisme. Dalam tulisannya tersebut, setelah sebelumnya melakukan identifikasi terhadap partai-partai sayap kanan yang terdapat di seluruh negara Uni Eropa, Taggart dan Szczebiak berhasil mengidentifikasi dua bentuk Eurosekptisisme yaitu Hard dan Soft Euroscepticism. Hard Euroscepticism sering dipahami sebagai penekanan agar negara keluar dari Uni Eropa. Sedangkan dalam Soft Euroscepticism, negara masih diperbolehkan berada dalam Uni Eropa, akan tetapi mereka harus lebih mengedepankan kepentingan nasionalnya dibandingkan dengan kepentingan Uni Eropa. ${ }^{5}$

Bahasan lain mengenai Euroskeptisisme juga dibahas dalam artikel Sofia Vasilopoulou yang berjudul Varieties of Euroscepticism: The Case of the European Extreme Right. Dalam tulisannya, Vasilopoulou berupaya untuk mengidentifikasi pandangan partai-partai sayap kanan di negara-negara Uni Eropa. Dari identifikasi yang

5 Alex Szczerbiak \& Paul Taggart, "Theorising Party-based Euroscepticism: Problems of Definition" dalam the 8th Biannual International Conference of the European Union Studies Association, Nashville, 27-9 March, 2003. 
telah ia lakukan, Vasilopoulou berhasil menemukan tiga bentuk baru dari Euroskeptisime yang didasarkan oleh penolakan partai sayap kanan terhadap prinsip, praktik, dan masa depan keterlibatan negara dalam integrasi Eropa yang saat ini mewujud dalam bentuk Uni Eropa. Bentuk Euroskeptisisme yang pertama ialah 'rejecting euroscepticism' yang merupakan penolakan secara penuh keterlibatan negara dalam integrasi Eropa, baik secara prinsip, praktek, dan upaya untuk terlibat pada masa depan. Bentuk yang kedua ialah 'conditional euroscepticism', yaitu penolakan terhadap keterlibatan negara dalam praktek dan proyeksi untuk bertahan maupun terlibat lebih jauh dalam integrase Eropa. Terakhir ialah compromising euroscepticism' yang memberikan toleransi pada negara untuk menganut prinsip dan turut aktif dalam integrasi Uni Eropa, tetapi tidak memperbolehkan negara untuk menjadikan keterlibatan permanen mereka dalam integrasi Eropa sebagai tujuan masa depan. ${ }^{6}$

Selain dua artikel diatas terdapat juga artikel dari Petr Kopecky dan Cas Mudde yang berjudul The Two Sides of Euroscepticism: Party Positions on European Integration in East Central Europe. Kopecky dan Mudde berupaya untuk mengamati kecenderungan pandangan partai-partai yang terdapat di negara-negara yang pada tahun 2002 sedang berstatus sebagai calon anggota Uni Eropa yaitu Hungaria, Polandia, dan Slovakia terkait penolakan atau penerimaan terhadap integrasi serta terhadap programprogram yang dijalankan atau dirumuskan oleh UE .

Berdasarkan data yang mereka dapatkan, pada akhir tulisannya Kopecky dan Mudde berhasil mengidentifikasi empat jenis pandangan terhadap integrasi Eropa. Pandangan pertama ialah Euroanthusiast, yaitu pandangan yang pro terhadap integrasi dan mendukung program-program rezim kerjasama regional di Eropa. Pandangan berikutnya ialah Eurosceptics, yaitu partai yang pro terhadap integrasi tetapi tidak mendukung program-program rezim kerjasama regional. Adapun pandangan ketiga disebut dengan Europragmatist, yaitu pandangan yang menolak integrasi, tetapi mendukung program-program rezim kerjasama regional. Pandangan terakhir disebut

'Sofia Vasilopoulou, "Varieties of Euroscepticism: The Case of The European Extreme Right" dalam Journal of Contemporary European Research, Vol. 5, No.1(2003), h. 3. 
dengan Eurorejects, yaitu partai yang anti integrasi, dan menolak program-program rezim kerjasama regional. ${ }^{7}$

Ketiga literatur yang dipaparkan diatas secara umum memiliki kesamaan berupa upaya identifikasi pandangan yang dianut oleh partai-partai di negara-negara Uni Eropa terkait penolakan dan penerimaannya terhadap integrasi Eropa. Identifikasi tersebut kemudian berujung pada ditemukannya bermacam tipologi dari Euroskeptisisme. Meskipun sama-sama berfokus pada Euroskeptisisme sebagai tema besar, tulisan ini lebih berfokus untuk mengkonfirmasi signifikan tidaknya perkembangan Euroskeptisisme di negara-negara Uni Eropa - terutama di Perancis, Belanda, Jerman, Italia, Belgia, dan Luksemburg, sebagai enam negara awal yang sejak lama tergabung dalam integrasi Eropa, melalui pengamatan terhadap kontestasi partai-partai politik pada tiga penyelenggaraan pemilihan umum terakhir di negara-negara tersebut.

Selain ketiga literatur diatas, terdapat juga literatur-literatur yang berupaya untuk mengamati Euroskeptisisme di beberapa negara Uni Eropa. Salah satunya ialah penelitian dari Michael Toomey yang mengomparasikan Euroskeptisisme di Polandia, Republik Ceko, dan Slovakia. Dari riset yang telah ia lakukan, Toomey menjumpai adanya skeptisisme berbasis elite yang tinggi di Polandia dan Republik Ceko, serta skeptisisme berbasis massa yang rendah di Polandia dan Slovakia. Pada akhir tulisannya Toomey berhasil mengidentifikasi adanya perbedaan faktor historis dan juga status ekonomi yang berpengaruh terhadap perbedaan skeptisisme akan integrase Eropa yang terjadi di tiga negara yang ia teliti. ${ }^{8}$

Tulisan lain yang juga membahas perbandingan Euroskeptisisme di negara anggota Uni Eropa juga tampak dari tesis Helle Schroder Hansen dengan judul Euroscepticism: A multidimensional understanding of the concept and a comparative analysis of public scepticism in Britain and Denmark yang menjelaskan kasus Euroskeptisisme di Denmark dan Inggris. Pada awal tulisannya, Schroder memulai dengan pertanyaan tentang sejauh mana Euroskeptisisme dianggap sebagai konsep multidimensional yang mempengaruhi proses integrasi Uni Eropa dan apakah konsep tersebut berbeda antara negara-negara anggota Eropa dan dari waktu ke waktu. Pada

\footnotetext{
7 Petr Kopecký \& CasMudde. "The two sides of Euroscepticism: party positions on European integration in East Central Europe" dalam European Union Politics, 3, No. 3 (2002), h. 297-326.

${ }^{8}$ Michael Toomey, Euroscepticism in Central Europe: A comparative analysis at elite and mass level of Poland, the Czech Republic, and Slovakia (Lund University: Spring, 2007).
} 
bagian selanjutnya Hansen berupaya memetakan Euroskeptisisme dengan mengacu pada empat indikator yaitu persepsi masyarakat tentang manfaat yang mereka peroleh dari kehadiran Uni Eropa, demokratis tidaknya Uni Eropa, memudar tidaknya identitas nasional negara yang bergabung dalam Uni Eropa, dan pandangan partai yang menolak keberadaan Uni Eropa. ${ }^{9}$

Melalui indikator-indikator tersebut, Hansen berhasil menemukan bahwa terdapat perbedaan bentuk Euroskeptisisme di Denmark dan Inggris. Di Denmark skeptisisme terhadap Uni Eropa tampak dari persepsi dominan masyarakat Denmark yang cenderung melihat Uni Eropa sebagai institusi yang kurang demokratis. Sementara itu, skeptisisme Uni Eropa yang terdapat di Inggris tampak dari persepsi masyarakat Inggris yang melihat kurangnya manfaat yang mereka peroleh dari keberadaan Inggris di Uni Eropa. Meskipun demikian, Hansen juga menemukan adanya kesamaan wujud skeptisisme terhadap Uni Eropa di Denmark dan Inggris dalam bentuk tingginya kecenderungan untuk menonjolkan identitas nasional dibandingkan dengan identitas keanggotakan negara mereka sebagai bagian dari Uni Eropa.

Seperti halnya Toomey dan Hansen, dalam tesis yangberjudul Euroscepticism in Right-Wing Parties: A Comparison of Three Emerging Right-Wing Parties, Carmen Schneider juga berfokus pada perbandingan Euroskeptisisme yang dianut oleh partaipartai sayap kanan di Jerman, Belanda, dan Inggris. Dengan menggunakan tipologi Euroskeptisisme yang dirumuskan oleh Sofia Vasiloupou, melalui pengumpulan data berupa manifesto partai dan pidato-pidato para pemimpin partai, penelitian Schneider menghasilkan temuan bahwa Partij voor de Vrijheid $(\mathrm{PvV})$ dari Belanda, dan Alternative für Deutschland (AfD) dari Jerman merupakan partai yang termasuk dalam kategori 'reject euroscepticism', yang menolak secara penuh keterlibatan Jerman dan Belanda dalam integrasi serta berbagai kerjasama bilateral maupun multilateral dengan negara-negara Eropa. Sedangkan United Kingdom Independence Party (UKIP) tergolong sebagai 'conditional euroscepticism', yang masih memberikan toleransi bagi Inggris untuk mengadakan kerjasama bilateral maupun multilateral dengan negaranegara Eropa lain, sejauh kerjasama itu memberikan keuntungan bagi Inggris.

${ }^{9}$ Hans Schroeder Hansen. "Euroscepticism -A Multidimensional Understanding of The Concept And a Comparative Analysis of Public Scepticism in Britain and Denmark". Master Thesis.(Denmark: Aalborg University, 2008). 
Meskipun demikian UKIP menolak jika Inggris bergabung atau memiliki orientasi untuk ikut serta secara aktif dalam integrasi Eropa. ${ }^{10}$

Secara umum literatur-literatur diatas dengan penelitian ini memiliki kesamaan berupa Euroskeptisisme sebagai tema sentral. Hanya saja terdapat perbedaan yang cukup jelas dalam hal fokus bahasan, yang didalmnya juga mencakup indikator yang dipakai dalam memetakan euroskeptisisme, seperti tulisan dari Toomey yang menggunakan perilaku elit politik dan masyarakat sebagai indicator yang ia gunakan untuk membandingkan dan menganalisa perbedaan bentuk skeptisisme Uni Eropa di Polandia, Republik Ceko, dan Slovakia. Sedangkan riset dari Hansen berfokus pada pelacakan mengenai kecenderungan Euroskeptisisme di Denmark dan Inggris melalui pemetaan terhadap persepsi masyarakat di kedua negara tersebut. Terakhir, riset yang dilakukan oleh Schneider berfokus pada identifikasi bentuk Euroskeptisisme yang dianut oleh $\mathrm{PvV}$, AfD, dan UKIP - yang merupakan partai sayap kanan di Belanda, Jerman, serta Inggris, dengan menggunakan tipologi Euroskeptisisme yang berbasiskan pada ideologi partai sebagaimana dirumuskan oleh Sofia Vasiloupoulou.

Berbeda dengan berbagai literatur yang telah dijelaskan sebelumnya, penelitian ini lebih berfokus untuk mengamati apakah sampai dengan tahun 2018, terdapat perkembangan Euroskeptisisme yang cukup signifikan di negara-negara inti Uni Eropa dengan menggunakan indikator capaian suara partai-partai sayap kanan di negaranegara tersebut pada tiga penyelenggaraan pemilihan umum terakhir.Guna melihat signifikansi tersebut, pada bagian selanjutnya akan diuraikan tentang kontestasi antar partai di enam negara pencetus integrasi Eropa yang meliputi Jerman, Perancis, Belanda, Belgia, Luxemburg, dan Italia.

\section{Metode Penelitian}

Penelitian ini memakai metode komparatif dengan teknik analisa data kuantitatif yang berfokus pada penggunaan data dalam bentuk 'angka' yang diperoleh dari analisis statistik.Metode komparatif sendiri menurut Lijphard merupakan metode analisis

${ }^{10}$ Carmen Schneider, "Euroscepticism In Right-Wing Parties A Comparison Of Three Emerging Right-Wing Parties”. Bachelor's Thesis. (Netherlands: University of Twente, 2014). 
mengenai sejumlah kasus kecil yang melibatkan sedikitnya dua pengamatan. ${ }^{11}$ Selain itu metode komparatif juga dapat dipahami sebagai metode yang dipakai untuk studi lintas nasional, yang bermaksud untuk meneliti isu-isu atau fenomena tertentu di dua negara atau lebih dengan tujuan mencari penjelasan maupun membuat generalisasi atas persamaan dan perbedaan. ${ }^{12}$ Adapun metode pengumpulan data dalam penelitian ini menggunakan metode dokumentasi atau library research yaitu pengumpulan data melalui dokumen berupa buku, jurnal, surat kabar, situs resmi pemerintahan, dan literatur-literatur yang berkaitan dengan fokus penelitian yang sedang dibahas. ${ }^{13}$

Pada umumnya, indikator yang sering dipakai dalam melihat berkembangnya euroskeptisisme ialah keberadaan dan popularitas partai-partai sayap kanan. Oleh karena itu, paparan inti dalam penelitian ini akan lebih banyak membahas tentang kontestasi antar partai di negara-negara Uni Eropa melalui hasil pemilihan umum pada tiga periode terakhir yang umumnya berlangsung pada kisaran waktu antara tahun 2007 hingga 2018, untuk kemudian dapat dipetakan bagaimana capaian hasil yang didapatkan oleh partai-partai sayap kanan di negara-negara Uni Eropa pada setiap pemilihan umum yang terselenggara di negara mereka. Dari pengamatan tersebut nantinya akan diketahui sejauh mana signifikansi perkembangan Euroskeptisisme di negara-negara Uni Eropa.

\section{Hasil dan Pembahasan}

Dinamika politik dalam negeri suatu negara salah satunya dapat dilihat darikontestasi antar partai politik dalam memperebutkan suara pemilih pada pemilihan umum yang berlangsung setiap periode. Setiap partai politik tentunya menjalankan kampanye yang biasanya berisi proyeksi pemerintahan selama satu periode kedepan, yang tentunya disesuaikan dengan ideologi atau platform yang mereka anut. Sebagai negara demokratis, Jerman, Perancis, Belanda, Belgia, Luxemburg, dan Italia, pada setiap periodenya senantiasa menjalankan pemilihan umum yang didalamnya berisikan kontestasi antar partai. Bahasan berikut akan menguraikan tentang track recordhasil

\footnotetext{
11 Arend Lijphart. "Comparative Politics and The Comparative Method" dalam American Political Science Review, 65, (3), (1971), h. 682-693. h. 2-11.

${ }^{12}$ Linda Hantrais, "Comparative research methods" dalam Social Research Update, 13 (Summer, 1995), 82.

${ }^{13}$ Umar Suryadi Bakry, Metode Penelitian Hubungan Internasional (Yogyakarta: Pustaka Pelajar, 2016), h.
} 
pertarungan antar partai di keenam negara tersebut pada setiap pemilihan umum sejak tahun 1993 guna melihat signifikansi euroskeptisisme di negara-negara tersebut.

\section{Perancis}

Perancis merupakan negara yang menerapkan sistem multipartai, dimana terdapat banyak partai yang bersaing untuk memperebutkan kursi di parlemen pada pemilihan umum yang diselenggarakan setiap lima tahun sekali. Pemilihan umum yang dilangsungkan berjalan sebanyak dua kali, yaitu pemilihan umum eksekutif untuk memilih Presiden, dan pemilihan umum legislatif untuk memilih anggota Majelis Nasional dengan masa jabatan masing-masing selama lima tahun. Baik Presiden maupun anggota Majelis Nasional dipilih secara langsung oleh masyarakat Perancis.

Pemilu eksekutif dilaksanakan lebih dahulu sebelum dilaksanakannya Pemilu legislatif. Karena masyarakat sudah melihat partai mana yang dianut oleh Presiden terpilih, biasanya mayoritas pemenang Pemilu legislatif berasal dari partai yang sama dengan Presiden. Presiden kemudian memilih Perdana Menteri yang berasal dari partai yang mendapatkan suara mayoritas dalam Pemilu legislatif atau anggota Majelis Nasional terpilih. Setelah itu Presiden dan Perdana Menteri bersama-sama membentuk kabinet.Sistem pemilihan umum yang digunakan di Perancis dikenal dengan istilah scrutin majoritaire, yaitu suatu sistem Pemilu di mana pemenang dalam Pemilu tersebut ditentukan berdasarkan suara terbanyak. Sistem ini dapat dibagi lagi menjadi dua mekanisme pelaksanaan yaitu satu putaran dan dua putaran. Meskipun demikian, Perancis tidak pernah memakai mekanisme Pemilu satu putaran. Perancis memakai mekanisme Pemilu dua putaran pada setiap penyelenggaraan Pemilu.

Dengan berlakunya sistem multi partai, secara garis besar peta politik Perancis dapat dikategorikan ke dalam dua kelompok besar yaitu partai atau kelompok politik beraliran kiri dan kanan. Partai-partai yang beraliran kiri berisikan partai-partai yang menganut dan mengadopsi nilai-nilai sosialisme dan demokrasi sosial. Sedangkan partai-partai yang ada di aliran kanan lebih bersifat konservatif, liberal dan kadang berisikan kelompok-kelompok kanan agama seperti partai Popular Republican Movement yang beraliran Christian Democratic. Ideologi Konservatif yang kebanyakan dimiliki oleh kelompok kanan kurang lebihnya merupakan ideologi yang berusaha 
mempertahankan sistem dan tatanan sosial yang sudah ada dan tidak menghendaki perubahan yang radikal. ${ }^{14}$

Kelompok-kelompok konservatif akan berusaha mempertahankan tradisi dari sebuah negara untuk tidak hilang atau pudar seiring dengan hadirnya tradisi-tradisi baru yang berkembang atau dibawa oleh para pendatang. Ideologi ini pula yang menjadi salah satu dasar dari kebijakan-kebijakan yang dikeluarkan oleh partai-partai dari kelompok kanan. Jika mengacu pada ideologi yang dianut oleh kelompok kanan Perancis, hingga saat ini partai-partai dari kelompok kanan terkenal vokal untuk memperjuangkan kebijakan anti imigran. Contoh kebijakan yang mencerminkan ideologi kanan sangat terlihat pada masa pemerintahan Jacque Chirac dan Nicholas Sarkozy di mana keduanya mengeluarkan kebijakan yang dapat dikatakan bersifat diskriminatif terhadap kelompok-kelompok tertentu.

Kepartaian Perancis yang bersifat multipartai ini mengakibatkan munculnya persaingan politik yang beragam. Sedikitnya terdapat 20 partai politik di Perancis. Beberapa diantaranya merupakan partai besar, seperti Partai Sosialis dan Partai Union for a Popular Movement. Kedua partai ini pada hampir setiap pemilihan umum mampu mendapatkan popularitas yang tinggi dan memperoleh suara terbanyak pada pemilihan umum di Perancis. Partai politik terbagi dalam posisi-posisi sesuai dengan misi yang mereka usung. Partai sosialis mengusung nilai-nilai sosialis dalam pemahaman dan ideologi partainya. Partai politik Perancis terbagi kedalam beberapa aliran, Left-Wings, Right-Wings, Greens, Centrists, Former Parties of Note, dan Far-right (Cerahwati, 2018). ${ }^{15}$

Kemudian pada tahun 2016 berdiri sebuah partai aliran tengah, dan untuk pertama kalinya sejak Perang Dunia II, pada Pemilihan Presiden tahun 2017, presiden terpilih bukan berasal dari dua partai utama, Sosialis dan Republik. Dari sini kemudian muncul polarisasi baru dalam politik Perancis. Hal ini tampak dari adanya kelompok partai yang memiliki visi pro-Eropa, pro-integrasi, dan pro-keterbukaan, serta kelompok partai yang anti-Eropa, dan anti-imigran. Kelompok partai yang disebut pertama merupakan hasil penyatuan dari aliran kiri dan kanan oleh partai En Marche

\footnotetext{
14ParsToday, "Tantangan-tantangan Pemerintahan Baru Perancis" dalam https://parstoday.com/id/radio/world-i39094-tantangan_tantangan_ pemerintahan_baru_perancis diakses 23 Februari 2019.

${ }^{15}$ Ibid.
} 
yang didirikan oleh Emanuel Macron. ${ }^{16}$ Sementara kelompok partai yang disebut terakhir merupakan hasil inisiasi dari Marien Le Pen yang berasal dari Partai Front Nasional.

Gambar 1: Perbandingan perolehan suara Empat Partai Besar pada Pemilu Perancis 2007-2017

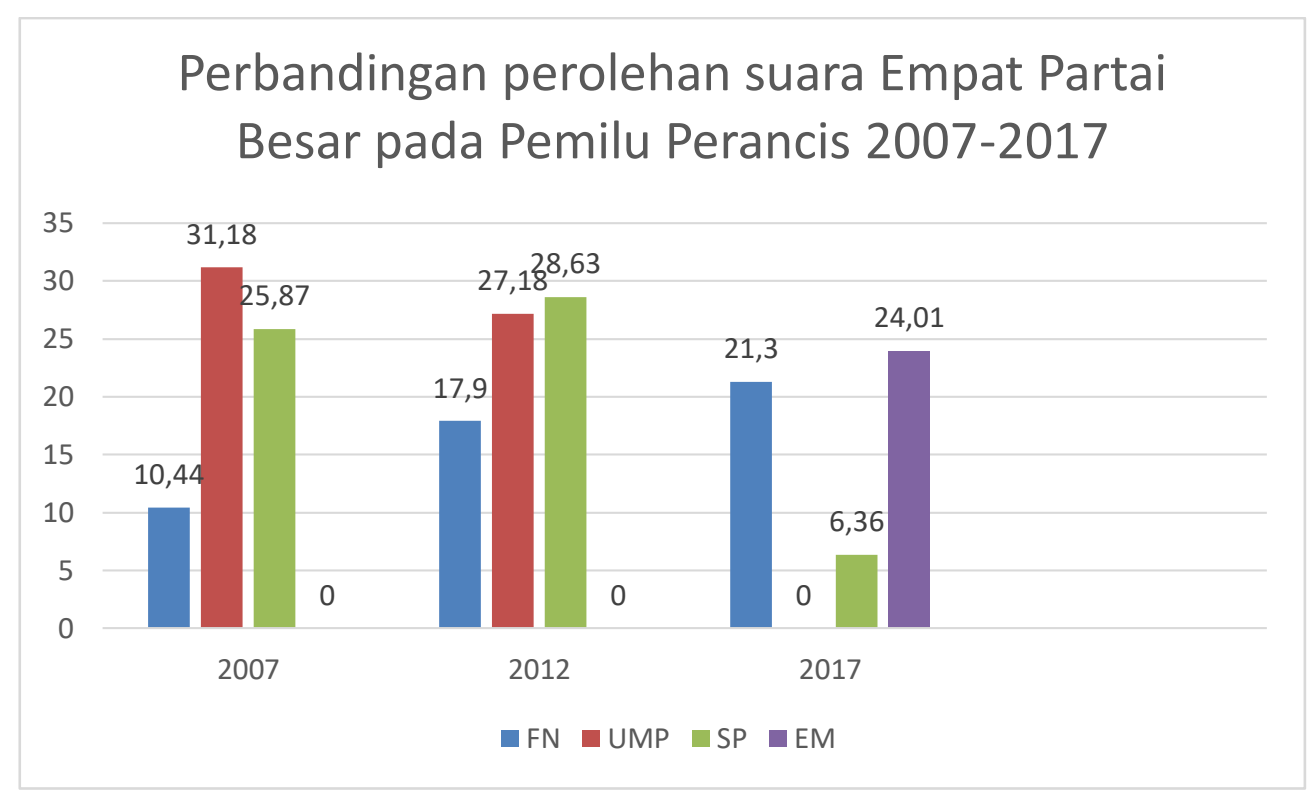

Sumber: https://www.conseil-constitutionnel.fr/

Kemenangan kelompok partai pro-Eropa dalam pemilihan umum tahun 2017, bukan berarti menggambarkan kesetujuan mayoritas masyarakat Perancis akan tetap bertahannya Perancis dalam integrasi Eropa. Jika melihat hasil pada pemilihan umum yang berlangsung pada tahun 2007 hingga 2017, secara prosentase terdapat peningkatan suara yang didapatkan partai Front Nasional pimpinan Marine Le Pen. Hal ini tampak dari gambar 1 diatas, dimana pada penyelenggaraan tiga pemilihan umum terakhir, perolehan suara Partai Front Nasional senantiasa mengalami peningkatan dari angka $10.44 \%$ pada $2007,17.90 \%$ pada 2012 , dan $21.30 \%$ pada 2017 . Perolehan suara Front Nasional pada 2017 bahkan membuat Marine Le Pen berhasil maju pada putaran kedua pemilihan Presiden Perancis, sebelum akhirnya dikalahkan oleh Emanuel Macron.Peningkatan suara dari Front Nasional menunjukkan bahwa terdapat kecenderungan akan meningkatnya sikap anti integrasi yang ditunjukkan oleh 
masyarakat Perancis, yang dapat dilihat dari penolakan sebagian besar masyarakat Perancis terhadap kebijakan Perancis dalam menyediakan tempat khusus bagi para imigran dari Timur Tengah. ${ }^{17}$

\section{Belanda}

Berbeda dengan Perancis, Belanda merupakan negara yang menganut sistem monarki konstitusional. Dalam sistem tersebut, Ratu merupakan Kepala Negara yang terikat pada konstitusi dan fungsinya lebih banyak bersifat seremonial. Meskipun demikian Ratu juga memiliki beberapa kewenangan yang merupakan kelanjutan dari tradisi the House of Orange seperti menunjuk formatur yang akan membentuk Dewan Menteri setelah dilakukan pemilihan umum. Secara umum Belanda memiliki tiga institusi utama dalam pemerintahannya yaitu Ratu, Dewan Menteri, dan Parlemen. Dewan menteri merupakan badan yang berfungsi merencanakan dan melaksanakan kebijakan pemerintahan. Menteri-menteri yang terdapat dalam Dewan Menteri tidak dapat merangkap menjadi anggota parlemen.

Sementara itu Parlemen Belanda merupakan Parlemen Bikameral yantg terdiri dari dua kamar, yaitu First Chamber dan Second Chamber. Dibandingkan dengan First Chamber, Second Chamber yang terdiri dari 150 anggota memiliki peran yang lebih penting karena adanya hak untuk mengusulkan rancangan undang-undang dan mengamandemen rancangan yang diajukan pemerintah, serta memilih anggota Ombudsman Nasional. Sedangkan First Chamber hanya memiliki hak untuk menyetujui atau menolak, tidak bisa untuk melakukan perubahan.

Seperti halnya Perancis, di Belanda juga terdapat banyak partai yang setiap periodenya bersaing dalam pemilihan umum. Pemilu yang diselenggarakan di Belanda merupakan pemilihan yang bertujuan untuk memilih anggota Second Chambers yang berlangsung setiap 2 hingga 5 tahun sekali. Sistem pemilu yang digunakan adalah sistem proporsional, dimana tidak ada batasan perolehan suara bagi partai untuk dapat mengikuti Pemilu. Sistem ini membuat pemerintahan yang terbentuk selalu pemerintahan koalisi. Koalisi besar biasanya terdiri dari koalisi Kristen dan Koalisi

17 Moddie Alvianto Wicaksono, "Dinamika Imigran Muslim di Perancis melalui Ruang Publik padaPemerintahan Nicholas Sarkozy" dalam Jurnal Transformasi Global, Vol. 4, No.2 (2017), h. 173. 
Partai-partai kiri. Sementara itu First Chamber terdiri dari 75 anggota yang dipilih oleh Dewan Provinsi untuk waktu 4 tahun. ${ }^{18}$

Koalisi Kristen terdiri dari partai-partai Kristen yang pro-Eropa dan proIntegrasi dan dipimpin oleh Volkspartij voor Vrijheid en Democratie (VVD) sebagai Partai yang mendapatkan suara tertinggi pada tiap penyelenggaraan pemilihan umum. Sementara itu koalisi Partai-partai kiri merupakan sekelompok partai yang anti-integrasi dan cenderung mengarahkan Belanda untuk mengevaluasi kembali keanggotannya dalam Uni Eropa. Koalisi tersebut terdiri dari 9 partai, dua yang terbesar diantaranya ialah Partij voor de Vrijheid (PvV) dan Partij van de Arbeid (PvdA).

Gambar 2: Perbandingan perolehan suara Koalisi Partai Kristen dan Partai Kiri pada Pemilu Belanda 2010-2017

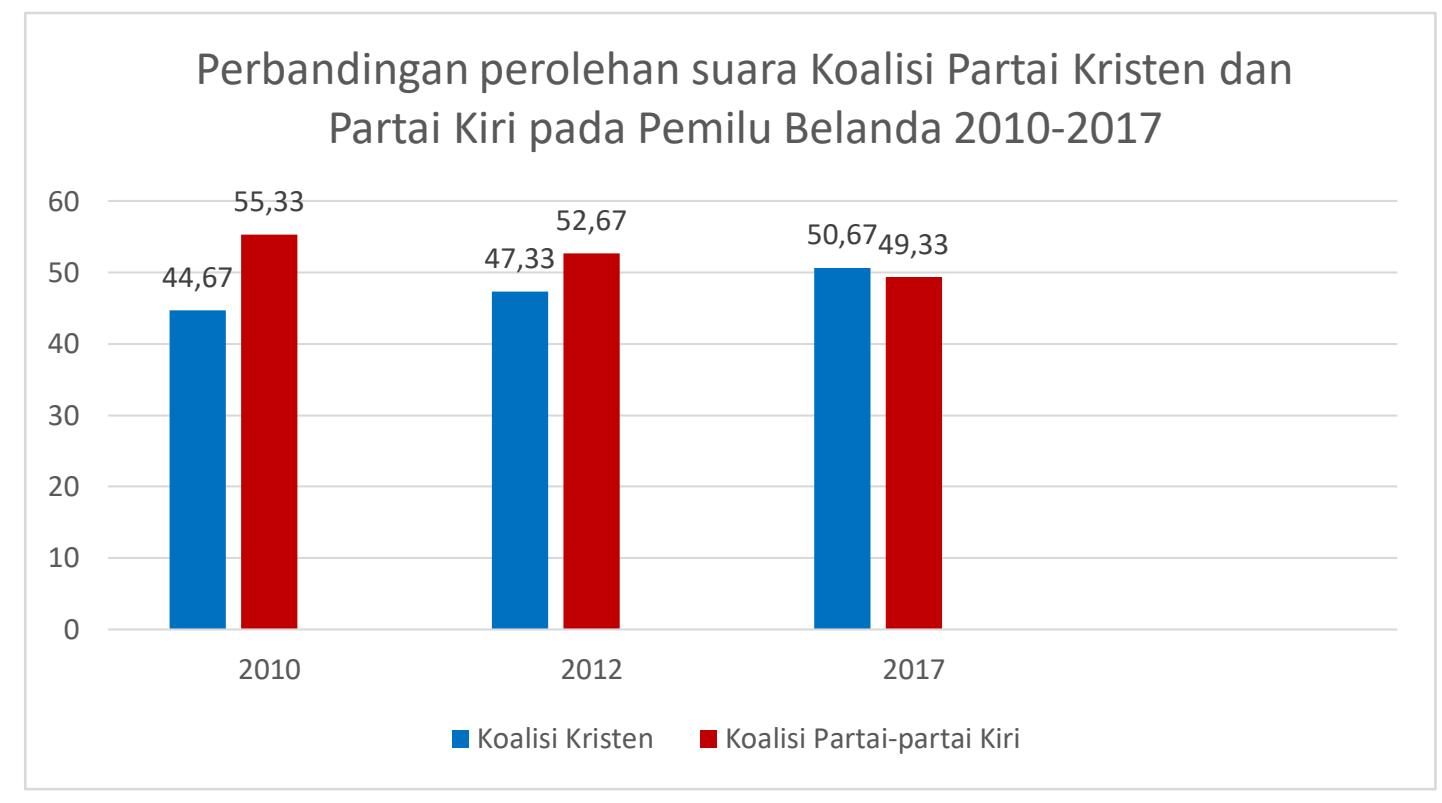

Sumber: https://english.kiesraad.nl/

Gambar 2 diatas menunjukkan perbandingan perolehan suara antara koalisi Partai Kristen dengan koalisi Partai-partai Kiri pada tiga pemilihan umum terakhir. Dari gambar tersebut dapat dilihat bagaimana prosentase perolehan suara koalisi Partai Kristen mengalami peningkatan. Tercatat pada tahun 2010 koalisi partai Kristen memperoleh $44.67 \%$, yang kemudian meningkat jadi 47.33 pada 2012, dan 50.67 pada 
2017. Hal yang sebaliknya dialami oleh koalisi partai-partai kiri. Dengan demikian, jika mengacu pada peningkatan prosentase suara yang diperoleh oleh koalisi Kristen, bisa dinyatakan bahwa hampir separuh masyarakat Belanda memiliki kecenderungan untuk bertahan dalam integrasi Eropa. Meskipun demikian, tipisnya selisih perolehan suara antar dua koalisi partai tersebut secara langsung menunjukkan masih tingginya tendensi anti integrasi masyarakat Belanda yang dapat dilihat dari tingginya islamophobia di negara tersebut. ${ }^{19}$

\section{Jerman}

Jerman merupakan negara demokrasi parlementer. Dalam sistem tersebut, kepala pemerintahan dipegang oleh seorang Kanselir, dan kepala negara dijabat oleh Presiden. Seperti halnya Perancis dan Belanda, Jerman juga memiliki lembaga legislatif yang disebut dengan Bundestag, yang berperan dalam memberikan usulan mengenai rancangan undang-undang serta melakukan amandemen terhadap rancangan yang diajukan pemerintah. Selain Bundestag terdapat pula Bundesrat, yang anggotaanggotanya adalah perwakilan pemerintahan negara-negara bagian. Berdasarkan konstitusi yang berlaku sejak reunifikasi, pemilihan umum di Jerman berlangsung setiap 4 tahun sekali. Dalam setiap penyelenggaraan pemilihan umum, masyarakat Jerman memiliki hak untuk memilih partai-partai yang saling bersaing mendapatkan kursi mayoritas di Bundestag. Partai pemenang yang mendapatkan suara terbanyak berhak untuk menempatkan kandidat utama yang telah diusung sebagai Kanselir.

Terdapat enam partai politik utama di Jerman, dengan tiga yang terbesar meliputi Social Democratic Party (SDP), Christian Democratic Union (CDU), dan Christian Social Union $(\mathrm{CSU}){ }^{20}$ Dua partai yang disebut terakhir pada perkembangannya berkoalisi secara permanen sehingga kemudian disebut sebagai CDU/CSU. Sementara itu partai-partai yang lain ialah Free Democratic Party (FDP), Die Grüne, dan Die Linke. Secara ideologis, jika mengacu pada pro kontra keikutsertaan Jerman dalam Uni Eropa, semua partai tersebut merupakan partai-partai yang pro-integrasi dan mendukung penuh keberadaan Jerman di Uni Eropa. Meskipun

\footnotetext{
19 Enes Bayrakli \& Farid Hafez, "2018 European Islamophobia Report | \#EIR2018” dalam http://www.islamophobiaeurope.com/, diakses 12 Desember 2019.

20 Wolfram Nordsieck, "Parties and Elections in Europe" dalam http://www.parties-andelections.eu/germany.html diakses 23 Februari 2019.
} 
demikian, pada April 2013 muncul partai baru yang bernama Alternative für Deutschland (AfD) yang berhalauan nasionalis dan memandang perlunya peninjauan kembali akan keikutsertaan Jerman di Uni Eropa. Sebagai partai baru, AfD baru mengikuti pemilihan umum pada Agustus 2013.

Gambar 3: Perbandingan perolehan suara Partai-Partai Besar pada Pemilu Jerman 2009-2017

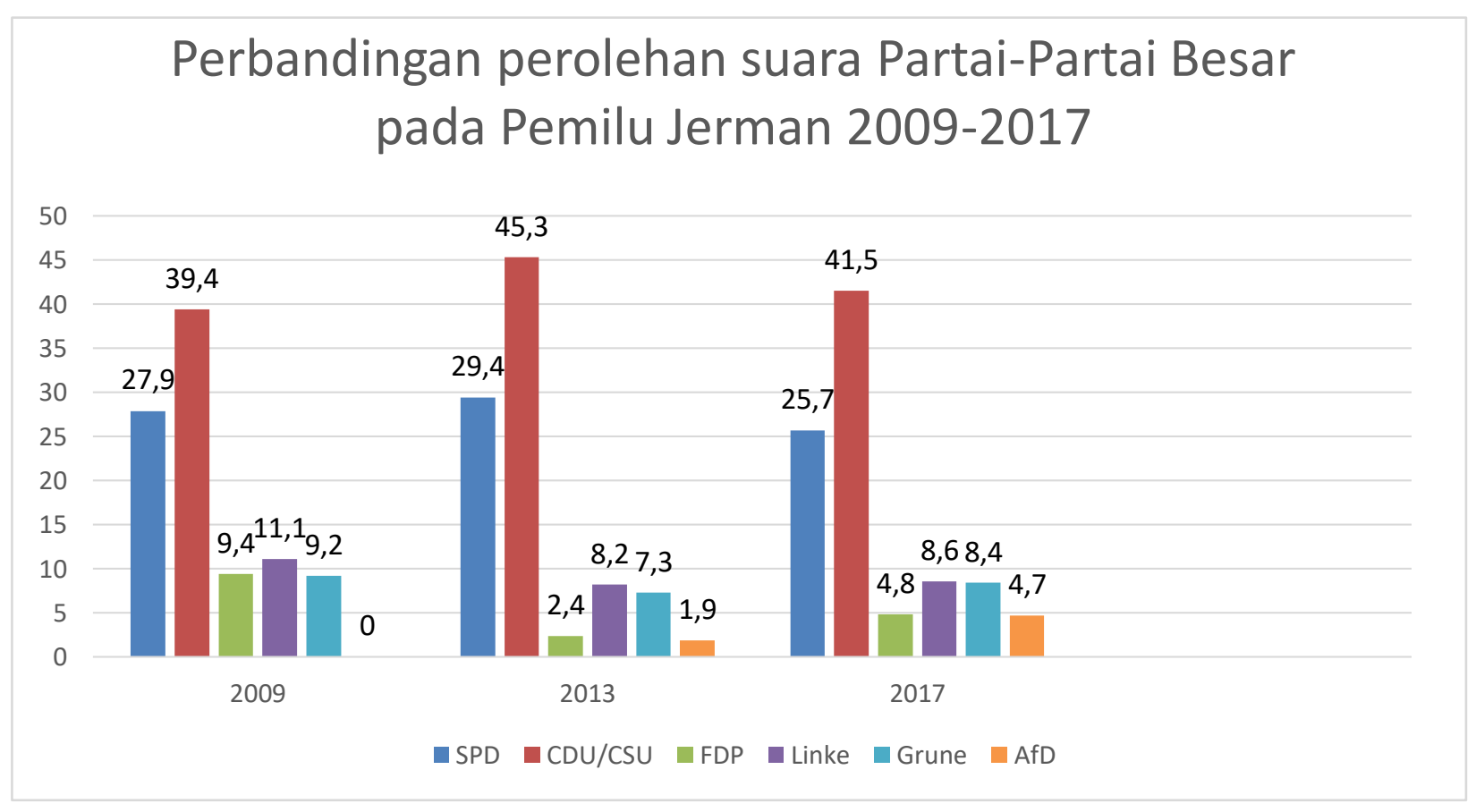

Sumber: The Federal Returning Officer-Bundestag Election

Dari gambar 3 diatas dapat dilihat bagaimana dalam pemilihan umum yang berlangsung sejak 2009, 2013, 2017, partai CDU/CSU mendominasi hasil perolehan suara.Sementara itu partai SPD secara konsisten berada pada posisi kedua.Baik CDU/CSU maupun SPD merupakan partai yang pro terhadap integrasi Eropa.Dengan demikian, jika dibandingkan dengan Perancis dan Belanda, kecil kemungkinan bagi Jerman untuk meninjau kembali keanggotaannya di Uni Eropa melalui referendum, mengingat dominannya partai-partai yang pro terhadap integrasi.

Meskipun demikian dalam pemilihan umum terakhir, partai AfD yang euroskeptis mengalami peningkatan suara, sekalipun masih belum mampu menggeser dominasi CDU/CSU.Sebagai partai yang baru berpartisipasi pada pemilihan umum 
tahun 2013, peningkatan suara sebesar 2,9\% pada pemilihan umum tahun 2017 menunjukkan adanya indikasi munculnya penguatan sikap penolakan masyarakat Jerman dalam integrasi Eropa. Sikap tersebut secara umum dilatarbelakangi oleh semakin banyaknya para imigran yang berdatangan ke Jerman sejak pemberlakuan open door policy sejak tahun 2015.Open door policysendiri merupakan kebijakan penerimaan pengungsi dari luar Jerman melalui penyediaan tempat penampungan sementara. ${ }^{21} \mathrm{Hal}$ ini pada gilirannya memicu adanya penolakan dari masyarakat Jerman, terutama mereka yang tergabung dalam kelompok-kelompok ultra kanan. Sampai dengan Juni 2019, berbagai kelompok ultra kanan tercatat telah terlibat dalam 8.605 kasus tindak kekerasan terhadap para imigran. ${ }^{22}$ Fenomena tersebut semakin menunjukkan adanya peningkatan tendensi penolakan masyarakat Jerman terhadap kebijakan-kebijakan pemerintah Jerman yang berprioritas pada Uni Eropa.

\section{Italia}

Berbeda dengan Jerman, Italia ialah negara republik parlementer. Dalam sistem tersebut, Perdana Menteri merupakan kepala pemerintahan yang bertanggung jawab dalam menetapkan kebijakan negara. Sementara itu Presiden berperan sebagai kepala negara. Meskipun demikian, keberadaan Presiden dalam struktur pemerintahan Italia bukan hanya sekedar sebagai simbol pemersatu. Lebih dari itu, Presiden memiliki wewenang untuk mengangkat Perdana Menteri beserta Dewan Menteri. Pengangkatan tersebut harus didasari oleh persetujuan dari Parlemen. ${ }^{23}$

Parlemen Italia merupakan lembaga legislatif yang terdiri dari dua kamar, yaitu Camera dei Deputatie (CdD) sebagai Majelis Rendah yang terdiri dari 630 anggota, dan Senato della Republika (SdR) sebagai Majelis Tinggi yang berisikan 315 anggota. Sekalipun bikameral, baik CdD maupun SdR tidak memiliki perbedaan peran dalam pemerintahan Italia. Hal ini berbeda dengan yang terdapat di Belanda maupu negaranegara lain, dimana Majelis Rendah cenderung memiliki kewenangan yang lebih luas

\footnotetext{
${ }^{21}$ Nadia Khansa Salsabila, “Aspek Pragmatisme Dalam Kebijakan Pintu Terbuka Jerman terhadap Pengungsi Timur Tengah: Solusi Grey Population” dalam Jurnal Hubungan Internasional, Vol.12, No.1, Januari 2019), h. 2.

22 Deutsche Welle, “Kekerasan Ekstrem Kanan di Jerman Meningkat Tajam 2019” dalam https://www.dw.com/id/kekerasan-ekstrem-kanan-di-jerman-meningkat-tajam-2019/a-50039036 diakses 12 Desember 2019.

23 Republik Italia, "The Constitution Of The Italian Republic" dalam https://www.quirinale.it/allegati_statici/costituzione/costituzione_inglese.pdf diakses 23 Februari 2019.
} 
dibandingkan dengan Majelis Tinggi. Satu-satunya perbedaan antara CdD dengan SdR hanyalah batasan usia anggota-anggotanya, dimana dalam SdR anggota yang masuk didalamnya harus berusia minimal 40 tahun.

Anggota-anggota dalam badan legislatif pemerintahan Italia ditentukan melalui pemilihan umum yang diselenggarakan setiap beberapa tahun sekali. Total terdapat 945 kursi dari CdD dan SdR yang diperebutkan oleh partai-partai politik yang saling bersaing. Secara umum, terdapat empat partai besar dalam sistem multi partai yang berlaku di Italia. Partai-partai tersebut ialah Il Popolo della Liberta (PdL) yang pada tahun 2013 berubah nama menjadi Forza Italia (FI), Lega Nord (LN), Partito Democratico (PD), dan Movimento 5 Stelle (M5S). Secara ideologis, berdasarkan pada pro kontra keikutsertaan Italia dalam Uni Eropa, PdL/FI dan PD merupakan partai yang pro-integrasi. Sementara itu LN dan M5S merupakan partai yang anti pada integrasi dan terus melemparkan wacana pada publik tentang perlu tidaknya Italia untuk tetap bertahan di Uni Eropa. ${ }^{24}$

Pada Pemilu 2018 masing-masing partai tersebut menyatu dalam dua koalisi besar dalam pemerintahan. Koalisi antara PdL/FI dan PD yang pro-integrasi sering disebut sebagai koalisi kanan-tengah. Sedangkan koalisi LN dan M5S yang antiintegrasi dikenal dengan koalisi kiri-tengah. Sekalipun demikian, koalisi antar partai dalam CdD maupun SdR tidak selalu statis. Artinya senantiasa terdapat perubahan dalam setiap penyelenggaraan pemilihan umum. Sebagai contoh, pada dua penyelenggaraan pemilihan umum sebelumnya, PdL berkoalisi dengan LN sebagai oposisi dari pemerintah yang saat itu dikuasai oleh PD pada 2013, dan sebagai partai berkuasa pada 2008 dengan PD sebagai oposisi. Fenomena berubahnya peta koalisi partai pada pemilihan umum 2018, menunjukkan adanya polarisasi baru berupa anti dan pro Eropa.

${ }^{24}$ Christian, "Italian Main Political Parties and Their Policies" dalam http://www.aalep.eu/italianmain-political-parties-and-their-policies diakses 23 Februari 2019. 
Gambar 4: Perbandingan perolehan suara Partai-Partai Besar pada Pemilu Italia 2008-2018

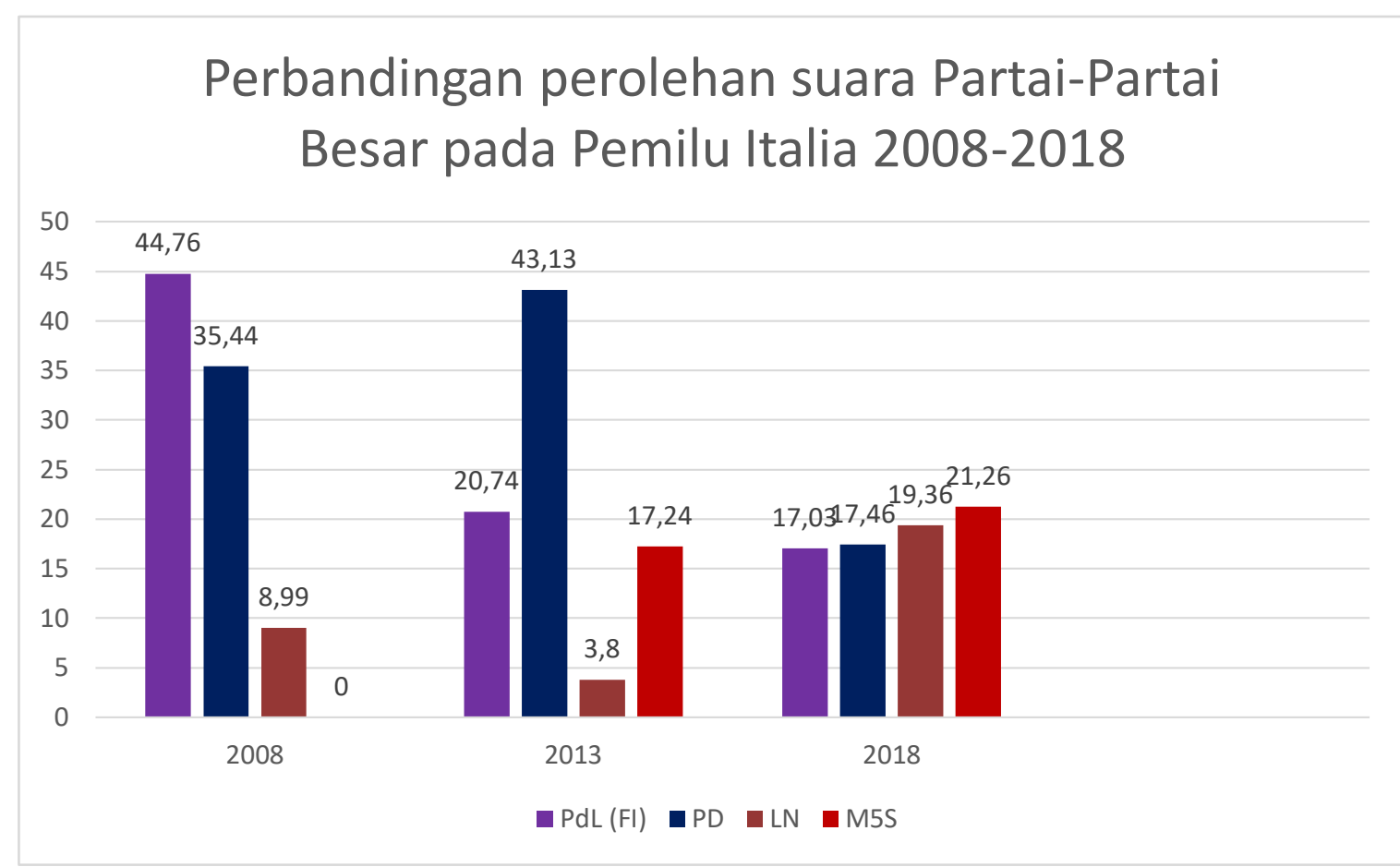

Sumber: www.politicaldatayearbook.com

Gambar 4 diatas menunjukkan bagaimana pada pemilihan umum tahun 2018 koalisi LN dan M5S yang euroskeptis berhasil mengalahkan koalisi PD dan PdL yang pro-integrasi. ${ }^{25}$ Padahal dalam dua pemilihan umum tahun 2008 dan 2013, baik PD maupun PdL merupakan dua partai dominan yang silih berganti memenangi pemilu. ${ }^{26}$ Dengan demikian kemenangan koalisi anti-integrasi pada pemilu 2018 bukan hanya sekedar simbol runtuhnya dominasi PdL dan PD, tetapi juga menunjukkan kecenderungan masyarakat Italia yang menginginkan pemberlakuan kebijakan pembatasan imigran dari luar Italia, sebagaimana yang senantiasa dikampanyekan oleh Giuseppe Conte, pemimpin koalisi koalisi LN dan M5S menjelang pemilihan umum 2018. Conte sendiri pada akhirnya berhasil menjadi Perdana Menteri Italia. ${ }^{27}$

${ }^{25}$ Piero Ignazi, “Italy” dalam European Journal of Political Research Political Data Yearbook, 52,1 (2013), h. 117-120. http://www.politicaldatayearbook.com/Chart.aspx/108/Italy, diakses 24 Februari 2019. /berita/731614/trump-puji-kebijakan-garis-keras-imigrasi-italia diakses 24 Februari 2019. 


\section{Belgia}

Belgia ialah negara monarki konstitusional yang menerapkan sistem demokrasi parlementer. Dalam sistem tersebut, Raja berperan sebagai Kepala Negara yang memiliki wewenang untuk menunjuk menteri-menteri, termasuk seorang Perdana Menteri, yang bersama-sama dengan Chamber of Representatives (CoR) untuk membentuk suatu pemerintahan federal. Sebagai kepala pemerintahan, Perdana Menteri memiliki wewenang untuk menetapkan kebijakan negara. Adapun CoR merupakan Majelis Rendah yang terdiri dari 150 anggota dalam badan legislatif pemerintahan Belgia yang bersifat bikameral. Sementara itu Majelis tinggi dalam badan legislatif Belgia disebut sebagai Senat yang beranggotakan 60 anggota. Sebagaimana parlemen bikameral pada umumnya Senat dalam pemerintahan Belgia memiliki peran yang lebih terbatas dibandingkan dengan $\mathrm{CoR}^{28}$

Anggota-anggota yang terdapat dalam CoR dipilih melalui pemilihan umum yang diselenggarakan setiap 3 hingga 4 tahun sekali. Terdapat empat partai dominan yang senantiasa bersaing dalam setiap pemilihan umum yaitu Christian Democratic and Flemish (CD\&F), New Flemish Alliance (NFA), Reformist Movement (RM), dan Socialist Party (SP). ${ }^{29}$ Dua partai yang disebut pertama sebelumnya merupakan koalisi permanen sebagaimana CDU/CSU yang terdapat di Jerman. Akan tetapi sejak tahun 2010 CD\&F dan NFA memilih untuk berdiri sendiri. Keempat partai tersebut secara ideologis merupakan partai yang sama-sama pro akan integrasi Eropa. Sehingga hasil perolehan suara pada setiap pemilihan umum yang terakhir diselenggarakan pada tahun 2014 lebih berefek pada dinamika internal yang terjadi di Belgia dan tidak terlalu memiliki pengaruh pada prospek keanggotaan Belgia di Uni Eropa.

\section{Luksemburg}

Seperti halnya Belgia, Luksemburg merupakan negara monarki konstitusional yang menerapkan sistem demokrasi parlementer. Secara umum terdapat tiga organ utama dalam pemerintahan Luksemburg yaitu Grand Duke sebagai kepala negara yang

\footnotetext{
${ }^{28}$ Belgian House Of Representatives, "The Belgian Constitution" dalam https://www.dekamer.be/kvvcr/pdf_sections/publications/constitution/GrondwetUK.pdf diakses 24 Februari 2019.

${ }^{29}$ Benoît Rihoux. et al. "Belgium" dalam European Journal of Political Research Political Data Yearbook, 56, 1 (2017), h. 31-35. http://www.politicaldatayearbook.com/Chart.aspx/106/Belgium,diakses 24 Februari 2019 .
} 
juga merupakan simbol negara, Perdana Menteri sebagai kepala pemerintahan, dan Chamber of Deputies (CoD) sebagai lembaga legislatif. Perdana Menteri merupakan sosok terpilih yang berasal dari partai atau koalisi dominan yang terdapat dalam Parlemen. Berbeda lembaga legislatif di lima negara yang telah disebutkan sebelumnya, Luksemburg menganut sistem unikameral yang artinya CoD hanya menjadi satusatunya badan yang berfungsi untuk mengusulkan rancangan undang-undang dan mengamandemen rancangan yang diajukan pemerintah.

CoD terdiri dari 60 anggota yang dipilih melalui pemilihan umum yang diselenggarakan setiap 4 hingga 5 tahun sekali. Meskipun di Luksemburg terdapat banyak partai yang ikut serta dalam pemilihan umum, akan tetapi hanya ada lima partai yang senantiasa dominan dalam setiap pemilihan umum yaitu Christian Social People's Party (CSPP), Luxembourg Socialist Workers' Party (LSWP), Democratic Party (DP), Green Party (GP), dan Alternative Democratic Reform Party (ADRP). Partai yang disebut pertama merupakan partai yang senantiasa menduduki posisi teratas pada setiap pemilu yang dilaksanakan sejak tahun 2004. Sementara itu ADRP merupakan satusatunya partai di Luksemburg yang cenderung anti-integrasi.

Gambar 5: Perbandingan perolehan suara Partai-Partai Besar pada Pemilu Luksemburg 2009-2018

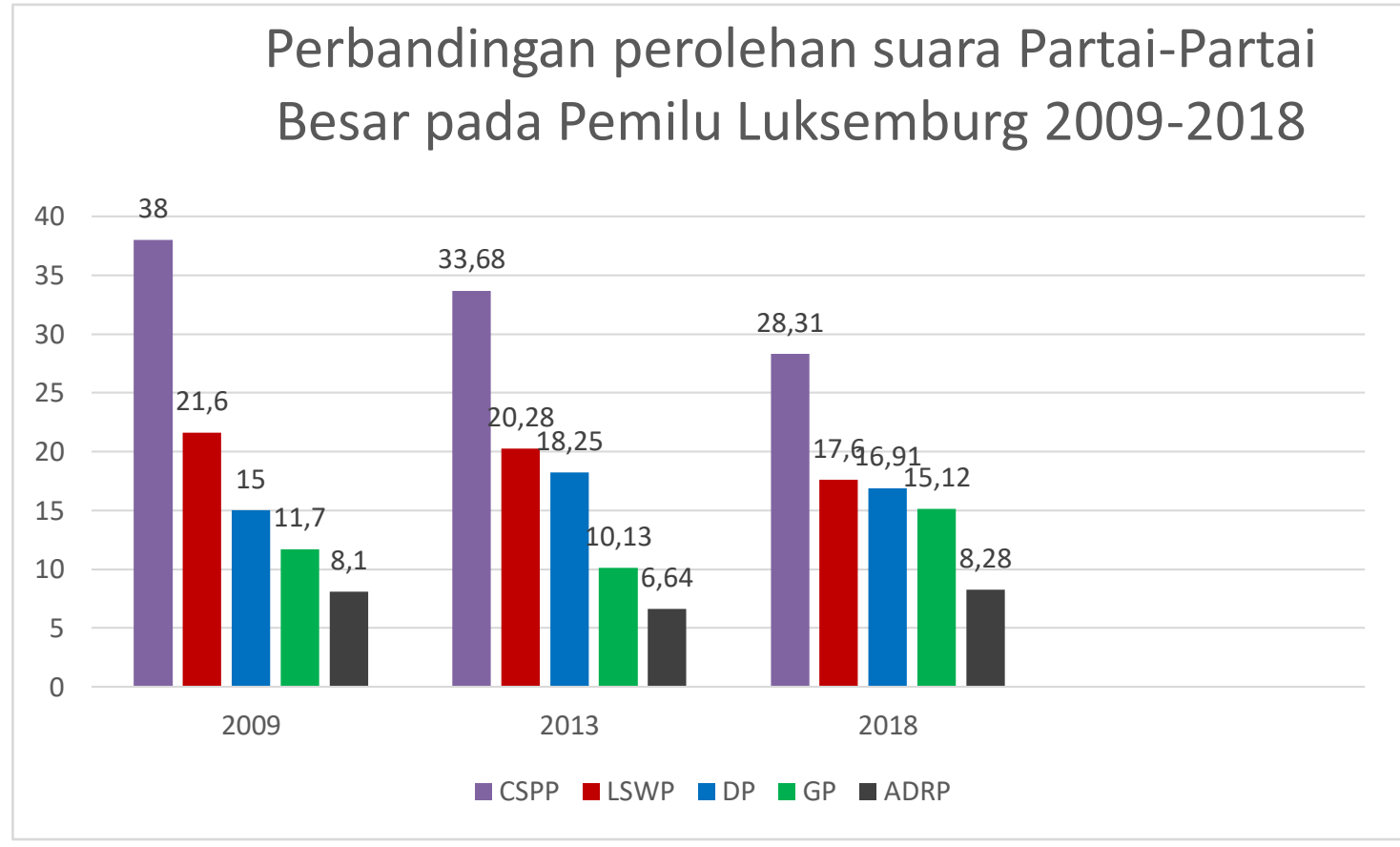

Sumber: www.politicaldatayearbook.com 
Dari gambar 5 diatas dapat dilihat bagaimana CSPP mendominasi perolehan suara dalam pemilihan umum yang berlangsung sejak 2009 hingga $2018 .{ }^{30}$ Sementara itu partai-partai lain seperti LSWP, DP, GP, dan ADRP secara konsisten menduduki posisi 2 hingga 5.Sebagai satu-satunya partai euroskeptis, ADRP masih belum mampu menggeser dominasi partai-partai lain yang pro-integrasi seperti CSPP, LSWP, maupun DP.Dengan mengacu pada hasil pemilihan umum tahun 2018, seperti halnya Jerman, kecil kemungkinan bagi Luksemburg untuk mengadakan referendum peninjauan kembali keanggotaan negara tersebut di Uni Eropa. Meskipun demikian peningkatan suara yang diperoleh partai ADRP menunjukkan adanya kecenderungan euroskpetisisme di Luksemburg.

\section{Kesimpulan}

Sebagaimana telah dijelaskan diawal, tujuan utama dari penelitian ini ialah untuk mengetahui signifikansi perkembangan euroskeptisime di negara-negara inti Uni Eropa melalui pelacakan terhadap hasil perolehan suara partai-partai yang pro dan anti/skeptic terhadap integrasi Eropa pada pemilihan umum yang dilangsungkan dalam kurun waktu 2007 hingga 2018.Dari data-data yang tercantum diatas, dapat dilihat bahwa dari enam negara inti di Uni Eropa, separuh diantaranya (Perancis, Belanda, dan Italia) memiliki potensi tinggi untuk mengadakan referendum sebagaimana yang telah dilakukan oleh Inggris. Untuk jangka panjang, tidak menutup kemungkinan partai-partai sayap kanan yang terdapat di Jerman dan Luksemburg akan menjadi salah satu partai besar yang mendapatkan banyak kursi di Parlemen, mengingat partai-partai sayap kanan di kedua negara tersebut memperoleh peningkatan suara pada penyelenggaraan pemilihan umum terakhir. Berbeda dengan kelima negara yang telah dijelaskan sebelumnya, dinamika antar partai di Belgia hanya berkisar pada persoalan antara Wallon dan Flemish.Berdasarkan paparan diatas, dengan demikian dapat disimpulkan bahwa terdapat potensi peningkatan Euroskeptisisme di negara-negara inti Uni Eropa.

\footnotetext{
${ }^{30}$ Patrick Dumont \& Raphaël Kies, "Luxembourg" dalam European Journal of Political Research Political Data Yearbook, 56, 1 (2017), h. 185-191. http://www.politicaldatayearbook.com/Chart.aspx/71/ Luxembourg, diakses 24 Februari 2019.
} 


\section{DAFTAR PUSTAKA}

Antara. "Trump Puji Kebijakan Garis Keras Imigrasi Italia" dalam https://www.antaranews.com/berita/731614/trump-puji-kebijakan-garis-kerasimigrasi-italia diakses 24 Februari 2019.

Bakry, Umar S. Metode Penelitian Hubungan Internasional. Yogyakarta: Pustaka Pelajar, 2016.

Bayrakli, Enes \& Farid Hafez. "2018 European Islamophobia Report | \#EIR2018” dalam http://www.islamophobiaeurope.com/, diakses 12 Desember 2019.

Belgian House Of Representatives. "The Belgian Constitution" dalam https://www.dekamer.be/kvvcr/pdf_sections/publications/constitution/Grondw etUK.pdf diakses pada 24 Februari 2019.

Christian. "Italian Main Political Parties and Their Policies" dalam http://www.aalep.eu/italian-main-political-parties-and-their-policies diakses pada 23 Februari 2019.

Deutsche Welle. “Kekerasan Ekstrem Kanan di Jerman Meningkat Tajam 2019” dalam https://www.dw.com/id/kekerasan-ekstrem-kanan-di-jerman-meningkat-tajam2019/a-50039036 diakses 12 Desember 2019.

Dumont, Patrick \& Raphaël Kies. "Luxembourg" dalam European Journal of Political Research Political Data Yearbook, 56, 1 (2017), h. 185-191. http://www.politicaldatayearbook.com/Chart.aspx/71/ Luxembourg, diakses pada 24 Februari 2019.

Hansen, Hans S. "Euroscepticism - A Multidimensional Understanding of The Concept And a Comparative Analysis of Public Scepticism in Britain and Denmark". Master Thesis. Denmark: Aalborg University, 2008.

Hantrais, Linda. "Comparative research methods" dalam Social Research Update, 13 (Summer, 2005), h. 2-11.

Harmsen, Robert \& Spiering, Menno. (Eds.).Euroscepticism: party politics, national identity and European integration. Amsterdam: Rodopi, 2004.

Heywood, Andrew. Global politics. London: Macmillan International Higher Education, 2014.

Ignazi, Piero. "Italy" dalam European Journal of Political Research Political Data Yearbook, 52,1 (2013), h. 117-120. http://www.politicaldatayearbook.com/ Chart.aspx/108/Italy, diakses pada 24 Februari 2019. 
Kopecký, Petr, \& CasMudde. "The Two Sides of Euroscepticism: Party Positions on European Integration in East Central Europe" dalam European Union Politics, 3, 3 (2002), h. 297-326.

Kouretas, Georgios P. \& Prodromos Vlamis. "The Greek Crisis: Causes and Implications" dalam Panoeconomicus 57, No. 4 (2010), h. 391-404.

Lijphart, Arend. "Comparative Politics and The Comparative Method" dalam American Political Science Review, 65, 3 (1971), h. 682-693.

Mansbach, Richard W. \& Kirsten L. Taylor. Introduction to Global Politics. Oxford: Routledge, 2007.

Nordsieck, Wolfram. "Parties and Elections in Europe" dalam http://www.parties-andelections.eu/germany.html diakses pada 23 Februari 2019.

ParsToday. "Tantangan-tantangan Pemerintahan Baru Perancis" dalam https://parstoday .com/id/radio/world-i39094-tantangan_tantangan_pemerintahan_baru_perancis diakses 23 Februari 2019.

Republik Italia. "The Constitution Of The Italian Republic" dalam https://www. quirinale.it/allegati_statici/costituzione/costituzione_inglese.pdf diakses pada 23 Februari 2019.

Rihoux, Benoît et al. "Belgium" dalam European Journal of Political Research Political Data Yearbook, 56, 1 (2017), h. 31-35. http://www. Politicaldatayear book.com/Chart.aspx/106/Belgium,diakses pada 24 Februari 2019.

Salsabila, Nadia K. "Aspek Pragmatisme Dalam Kebijakan Pintu Terbuka Jerman terhadap Pengungsi Timur Tengah: Solusi Grey Population" dalam Jurnal Hubungan Internasional, Vol.12, No.1, (Januari 2019), h. 1-16.

Schneider, Carmen M. "Euroscepticism In Right-Wing Parties A Comparison Of Three Emerging Right-Wing Parties". Bachelor's Thesis. Netherlands: University of Twente, 2014.

Susilo, Mohamad. "Bagaimana Macron Hanya Butuh Satu Tahun Untuk Jadi Presiden Prancis?" dalam https://www.bbc.com/indonesia/dunia-39838863, diakses pada 23 Februari 2019.

Szczerbiak, Alex \& Paul Taggart. "Theorising Party-based Euroscepticism: Problems of Definition" dalam the 8th Biannual International Conference of the European Union Studies Association, Nashville, 27-9 March, 2003.

Toomey, Michael. Euroscepticism in Central Europe: A Comparative Analysis at Elite and Mass Level of Poland, the Czech Republic, and Slovakia. Lund University: Spring, 2007. 
Vasilopoulou, Sofia. "Varieties Of Euroscepticism: The Case of The European Extreme Right" dalam Journal of Contemporary European Research, 5(1), (2003), h. 323.

Wicaksono, Moddie A. "Dinamika Imigran Muslim di Perancis melalui Ruang Publik pada Pemerintahan Nicholas Sarkozy" dalam Jurnal Transformasi Global, Vol. 4, No.2 (2017), h. 170-190. 